\title{
DOCUMENT
}

\section{FUNDAMENTALS OF THE MILITARY DOCTRINE OF MONGOLIA}

The defense policy and activities of the Mongolian State form part of the measures to ensure its national security. The Military Doctrine is one of the fundamentals of this policy and related activities in the area of defense.

The Military Doctrine is the official state concept defining the basis of state policy on war and aggression, averting and eliminating the danger of war, creating the conditions of and defending the country from aggression, on the organization of the armed forces and other troops as well as on waging armed struggle. It is based on the constitutional principle of self-defense.

Although the prospects for mutual understanding, trust and partnership have come to prevail in international relations with the end of the Cold War, the danger of war and armed conflict has not been fully eliminated, and a collective security system has not yet been formed in the world in general and the AsiaPacific region in particular.

Hence there still exists the threat of global and local wars as well as armed, ethnic and border conflicts.

In pursuing its peace loving policy of creating favorable external conditions for ensuring national security and preventing any threat of war and aggression in conformity with the universally recognized principles of international law, Mongolia shall:

not view the use of force or the threat of use as a means of settling any dispute and shall not recognize the results of such use of force or aggression;

not be part of any military alliance unless the independence and sovereignty of Mongolia is directly threatened or there is a clear and present danger of such a threat;

strictly adhere to the policy of not allowing foreign troops to enter be stationed in or pass across its territory in the absence of relevant Mongolian legislation.

Any country that threatens or undertakes armed aggression against the independence and sovereignty of Mongolia, and any accomplice to such an aggression, shall be regarded as its enemy. Mongolia shall wage an armed struggle and just war to defend itself against foreign armed incursion and aggression. 
Mongolia shall consider the following circumstances as aggression:

an intrusion into Mongolian territory by the armed forces of any other country;

an armed attack on Mongolia from beyond its borders;

attacks and/or assaults upon the Mongolian armed forces by any other country;

the violation of relevant Mongolian legislation by foreign troops during their stay in or transit through its territory;

the use by any other country of land leased to it under Mongolian law, for any armed aggression, however short or long in duration, against other countries;

the instigation of disorders, looting, subversive and terrorist activities perpetrated by specially trained and armed infiltrators from other countries into Mongolian territory

Proceeding from its national security and foreign policy concepts. Mongolia shall give priority to political and diplomatic means in the attainment of its defense objectives.

The supreme objective of the Mongolian State is to consistently pursue a foreign policy aimed at preventing ail wars and armed conflicts in the world and especially in the Asia-Pacific region, actively participating in the creation of collective security systems, diversifying its. Foreign partners, promoting its national interests and ensuring national security by political means

Mongolia shall declare its territory a nuclear-weapons-free zone and shall strengthen itself by multilateral guarantees. It shall actively promote the policies and activities aimed at banning nuclear testing and reinforcing the nuclear nonproliferation regime.

Mongolia shall vigorously support international efforts aimed at banning the development, production, stockpiling and use of weapons of mass destruction and at their elimination. It shall cooperate with other countries and international organizations in this regard.

Mongolia shall develop friendly relations and cooperation with all the countries of the world, particularly with neighboring states, and work toward bringing about military trust. It shall refrain from and prevent any activity that may adversely affect its vital national interests, and shall thereby eliminate any grounds for and causes of external military threats.

It shall establish and develop military relations with the UN forces, international military organizations and influential countries. 
It shall work toward creating and strengthening an integral defense system, and toward increasing the capabilities of its armed forces and other troops.

The Mongolian State shall pursue a firm policy of preventing any internal public disorder and armed conflict that could undermine the state and social order established by the Constitution, and national unity.

Dynamic economic development, resiliency under any circumstances, scientific and technological progress, a high level of public health, education, professional and military training, and the people's patriotism are the basis of the country's defense capability.

In peacetime. Mongolia shall have compact and efficient armed forces and other troops that are capable of meeting all defense and requirements and at the same time are commensurate with its economic means.

The functions, organizational principles, structure, command system as well as the terms of service in the armed forces and ether troops shall be established by law.

The general purpose troops are the core of the armed forces, and are the main force to defend the country by military means.

In peacetime, the general purpose troops shall direct their activities toward ensuring the armed forceps's ability to mobilize, providing military training, ensuring the replenishment of personnel, and organizing the protection, maintenance and servicing of military equipment and stockpiles.

In times of peace and war, the air defense forces are to safeguard the inviolability of the country's air frontiers, and to defend economic and administrative centers as well as all other vitally important regions from enemy attack.

In peacetime, the construction corps is to pursue construction activities. At the same time, they shall also be trained to fulfill missions according to mobilization requirements.

In times of peace and war, the civil defense forces are to be ready to provide rescue and relief activities in cases of the use of mass destruction weapons, of natural disasters and other large-scale calamities and industrial accidents which threaten the security of the population and may lead to enormous human casualties and damage to health and property.

The mobilization reserve consists of reservists and is intended to expand the armed forces by mobilization and to replace losses incurred in wartime.

In peacetime, the border troops are obliged to guard the frontiers, and to search and detain intruders. In wartime, they shall defend the frontiers, repulse armed incursions and neutralize intelligence and subversive activities. 
In peacetime and states of emergency, the internal troops are obliged to protect the country's vitally important objects and perform mission functions as prescribed by law.

The armed forces and other troops shall ensure peacetime preparations for fulfilling the required task of repulsing aggressors.

In the event of armed aggression, Mongolia shall repulse it and conduct a defensive war mobilizing all its strength and capabilities, which shall involve the participation of the entire population. In doing so, Mongolia may enlist the support and assistance of other countries and international bodies in accordance with the UN Charter.

The central and local administrations, all economic units and voluntary organizations, as well as all citizens shall be actively involved in implementing the military doctrine of Mongolia.

The implementation of the military doctrine of Mongolia shall be regulated by legislation and supervised by the President of Mongolia.

The military doctrine of Mongolia shall be adjusted according to changes in the country's military-political situation, as wall as in the economic, scientific, technological, and military fields at global and regional levels. 
D.Dashpurev and Usha Prasad. Mongolia: Revolution and Independence, 1911-1992.

New Delhi: Subhash \& Associate, 1993. Viii 148 p., appendix, Bibliography

D.Dashpurev and S. K. Soni. Reign of Terror in Mongolia, 1920-1990. New Delhi: South Asian Publishers, 1992. Viii, 93 p., appendix, bibliography. index.

With these two books, Dr. Dashpurev, who is currently the director of the Institute of Philosophy and Sociology of the Mongolian Academy of Sciences, is ushering in a new stage in Mongolian historiography To the best of my knowledge, they are the first English-language books written by a Mongolian scholar on this period using primarily materials which until the early 1990s had been kept from public view in the archives of MAKhN, the Mongolian communist party, and the Dotood Yam, the Mongolian secret police. The two books complement each other quite well, with the Mongolia book painting a broad picture of major events and the Reign book providing the chilling details of the specific subject of terror unleashed on the Mongolian people over a seventy-year period I will discuss the two books in the order in which they are listed above.

\section{A. MONGOLIA: REVOLUTION AND INDEPENDENCE.}

After a brief summary of Mongolian attempts to shake off Manchu rule during the nineteenth century, Dashpurev devotes Chapter 1 to the 1911 revolution and its main objective of national independence. He ably presents a resume of how, despite the enormous odds facing him. The Bogdo Khan doggedly pursued his goal of enlisting Russia as a selfless protector of Mongolian independence. Moving on to the second revolution, in 1921, Dashpurev notes that the Bogdo Khan and several of the key leaders of 1911 were also instrumental in bringing about the second revolution. The latter sought, in addition to securing a still fragile independence, the unification of all Mongols, meaning in the first place Inner Mongolia but also the Buryat area and Tannu Tuva. However, the new, communist, leaders of Russia added a third objective, social transformation, which they forced the Mongols to adopt. At the same time, the goal of unification had to be abandoned because it interfered with the Soviet plan to use Mongolia as a stable buffer against China and, later, Japan and its puppet Manchukuo. Likewise, all attempts by the Mongolian government to establish relations with other countries were thwarted. 
In Chapter 3, the author takes the Mongolian-Soviet military agreement of 1936 as the beginning of virtually total Soviet control over Mongolia that would last without interruption until 1990. Using the Japanese occupation of China's Northeast, which bordered Mongolia, as a pretext, the Soviets secured with this agreement the right to station troops in Mongolia and then proceeded to provoke fighting with Japanese and Manchukuo troops, culminating in the battle of Khalkhijn Gol in 1939. That military operation cost Mongolia dearly but not nearly as dearly as the bloody destruction of the Buddhist clergy. According to the author, Moscow presented an ultimatum to the effect that if the Mongolian government did not kill the monks, the Soviets would no longer protect Mongolia, a threat, made in the context of the late 1930s, that could not be ignored.

After World War II, the Sovietization of Mongolia went apace, especially in the three decades under Tsedenbal. Dashpurev describes how Molotov and his puppet Tsedenbal took every opportunity to keep Mongolia isolated from the outside world, particularly the events surrounding Mongolia's attempt in 1946 to join the United Nations. Not until a change of leadership in the Kremlin and with it a change in policies took place would Mongolia gain membership in the world body. The date was October 27, 1961. The book also relates the several attempts by Tsedenbal to have Mongolia absorbed into the Soviet Union, and his adamant refusal to stand up for Mongolia's national interests, such as in the negotiations leading to the border agreement with the Soviet Union in 1957. Sovietization reached its peak by the early 1970s when Tsedenbal decreed the use of the Russian language in government and at the country's main university. To top it off, appointments to higher government positions went only to persons fluent in Russian. Toward the end of the Tsedenbal era in the 1980s, Mongolia was flooded with not only Soviet troops but also more than 100,000 advisors without whose agreement little could be accomplished in any sphere of public life.

The last forty pages of the Mongolia book describe how Mongolia's third revolution began as an underground movement during the period of perestroika, with Shine Use (Now Generation) being the catalyst for the democratic forces. The first victory was scored on March 9, 1990 when the country's communist leaders resigned. This was followed by the first free election in July of that year, in which the democratic forces garnered $38 \%$ of the votes. The book ends with the second election, held in 1992, which marked a severe setback for the democratic parties because they only managed to win five of the seventy-six seats in the State Great Khural. 
The book ends with an appendix containing the text of the country's 1992 constitution and a fairly extensive bibliography. Chapter 7 is peculiar. It should have been a second appendix because of the nature of its contents. It is entitled "Some Remarks on Current Affairs", yet almost the entire first section deals with the history of Mongolia's relations with Tibet. The second section addresses current relations with India, and the last section is a brief discussion of the role the Secret History of the Mongols has played in twentieth-century Mongolia.

\section{B. REIGN OF TERROR IN MONGOLIA.}

The author sets the tone of this interesting book with the very first sentence of his introduction where he flatly states that a "study of Mongolia's immediate past can largely be taken up as a history of Communist terrorism" which he defines as "the use of force ... to achieve ... illegitimate political ends".

The book is arranged into three main chapters, each describing one of three phases of terrorism carried out by MAKhN, its secret police, and its Soviet overlords against the Mongolian people. The first phase began in 1922 under the guidance of the Buryat communist Rinchino who had been given key positions in the Mongolian party and government. The first major victim was Bodoo, the prime minister, soon followed by Danzan, a party leader. Shocking as these murders were, they were merely the beginning of far bloodier events to come, first during the confiscation of property in the late twenties and early thirties, and then during the second phase of terrorism which climaxed toward the end of that decade with about 90,000 lamas (p. 42) and many other persons murdered by Choibalsan's secret police and NKVD agents sent from the Soviet Union Dashpurev ends this chapter with some valuable personal recollections. All told, he estimates that about $15 \%$ of Mongolia's total population were executed during that time (p. 45).

The third phase of terrorism covers the more than three decades of Tsedenbal's dictatorship from 1952 to 1984 . While the number of persons murdered was far smaller than during Choibalsan's purges this new phase was marked principally by psychological terror applied against the country's intellectuals, most prominently against B. Rinchin. Even after the Soviets removed Tsedenbal from power in 1984, the terror did not stop. A whole bevy of his lieutenants continued to oppress intellectuals and others, and it was not unti ${ }^{1}$ the democratic revolution of 1990 that seven decades of political nightmare came to an end. The book ends with a substantial bibliography and a description of the sources used. 
It is regrettable that the Mongolia book's full potential was not achieved because of a lack of competent editing. Nevertheless, I see at least three valuable contributions both books have made toward the historiography of modern Mongolia. In the first place, it is encouraging to see a Mongolian scholar undertake the emotionally difficult task of reinterpreting his country's modern history Second, the interpretation of events offered in both books differs not only from previous Mongolian works (which were obliged to toe the political line of the day) but also from Western works, thereby providing all of us with a richer perspective. And third, with these two books having provided the first step toward the systematic use the recently opened archives, we can confidently look forward to many more books devoted to the study of twentieth-century Mongolia.

Paul Dibb. Toward a New Balance of Power in Asia. London: International Institute for Strategic Studies, 1995, 93 p., map, tables, notes, appendix (Adelphi papers; 295).

Paul Dibb, a former high-ranking official in the Australian government and currently the head of the Strategic and Defense Studies Center at Australian National University, surveys the strategic landscape of most of Asia, leaving out the western and central parts of the continent. He starts out with a brief history of the balance-of-power concept. He takes note of arguments that the concept is outdated but concludes that at least in Asia, particularly East Asia with its strong Confucian tradition of order and a strong state, it is alive and well. Balancing power will be more difficult because the world has shifted from the bipolar configuration of the Cold War to multiplicity. Dibb warns that military power is much too dangerous a tool to maintain a balance; at the same he warns against the current euphoria over economic development because "economic interdependence alone does not guarantee peace" (p. 72). What is needed; he argues, is a combination of military, political and economic measures.

Taking 2010 as his target date, Dibb sees five great powers in Asia China, Japan, India, Russia, and the United States - followed by the ten middle powers of the two Koreas, Taiwan, Vietnam, Thailand, Malaysia, Singapore, Philippines, Indonesia, and Pakistan. The remaining small powers include Mongolia. He sees two possible scenarios for China. The first is a country that will use its economic power to have its views accepted in both Northeast and Southeast Asia. At the same time, it will greatly increase its military potential to make its political pressures more persuasive. The second scenario sees the 
uneven economic growth within China leading to the country's breakup. This calamity might then be used by the Chinese leadership to undertake aggressive military policies abroad. Obviously, both of these scenarios would have disastrous consequences for China's neighbors, particularly for Mongolia. Dibb is much less certain, about Russia in 2010 . The country will be preoccupied with its domestic problems for at least the next decade during which Asia, particularly Northeast Asia, will receive a low priority in Moscow. The other external power, the United States, has also refocused on domestic matters and is likely to diminish its strategic role in Asia. At the same time, Dibb finds American insistence on human rights issues as an unwelcome and basically counterproductive policy.

He predicts that there will be neither a consensus among the great powers nor any general regional collective arrangement. Instead, there will be, or should be, a careful tending by each great power of equilibrium by an application of military, political and economic measures. He does, however, leave the door open for China's possible rise to hegemony in East Asia and beyond. If China should decide to challenge the United States and Japan for strategic influence in Asia, it could cause regional realignments but no formal coalition to offset Chinese power.

Whatever the great powers will do, Dibb sees little choice for the middle powers but to follow policies of military self-help and, whenever possible, strategies of cooperation to keep them from being pressured by one or more of the great powers. Although he does not say so explicitly, much the same could be said for the smaller powers, except that they could do less in military self-help and would have to compensate for this inability with more emphasis on cooperative strategies. In this context, it should be noted that Dibb believes that "Northeast Asia [in which he includes Mongolia] seems likely to develop its own sub regional security forum in the longer term" (p. 59). It is likely that the middle powers will continue to welcome the presence of American power in the region as long as the United States does not try to contain China (which would be highly counterproductive) or to insist that its own, or Western, definitions of human rights be accepted by Asians.

Dibb's well-researched presentation is backed up by three tables showing, inter allay, that Asia's total and per capita GNPs are growing much faster than those in North America and Europe and that by 2010 Asia's share of world output will be more than $70 \%$ of North America's and Europe's combined. The book concludes with an appendix containing a technical appraisal of the five great powers' military capabilities in 2010 . 
John Naisbitt. Megatrends Asia: Eight Asian Megatrends That Are Reshaping Our World. New York, etc: Simon \& Schuster 1996298 p.

If the Dibb book can be described as a good representative of thoughtful and competent scholarship, this book is something else. The introduction proclaims a "commonwealth of nations" arising in Asia through "economic symbiosis", and that this entire continent is now "working together for mutual economic gain". This purported future of the entire continent of Asia is said to be determined by the following eight "mega trends" presently at work: (1) from nation-states to networks; (2) from traditions to greater individualism; (3) from export-led to consumer-driven; (4) from government-controlled to market-driven; (5) from farms to super cities; (6) from labor-intensive industry to high technology; (7) from male dominance to the emergence of women; and (8) a shift of the global center of gravity from West to East. The author strongly implies, and sometimes explicitly states, that these trends will continue into the foreseeable future everywhere in Asia.

Unless somehow any reader of this book was not near a newspaper, radio, or television set during the past several years, he will instantly recognize these items because they have crowded the headlines of the world's media for many a moon, and have been discussed and pontificated upon by scores of commentators. Quite naturally, the reader is entitled to expect to find inside this book the reasons why the author thinks that these eight trends arose in the first place, why they apply to all of Asia, and why they will continue in the future.

To begin with the author's claim of forecasting all of Asia's future, this book does emphatically not cover all of Asia. The heaviest emphasis is on the ASEAN countries, particularly Singapore. Other countries, like Laos, Nepal, North Korea, Pakistan, and the vast bulk of China outside the coastal provinces, are barely mentioned. And, if the "thousands of business leaders and opinion makers in the Americas, "Europe, and Asia" who listen to Nesbit each year, as the boastful blurb on the dust jacket informs us, use this book as a primary source of information, they would not ever be aware of the existence of Mongolia, the five post-Soviet Central Asian republics, Iran, and the rest of West Asia. The maps on the end papers drive this point home; this whole vast "other Asia" is shaded dark and devoid of any identification. It is Naisbitt's terra incognita.

As for the book's content, it should be noted that not one of the eight chapters offers the reader cogent and cohesive argumentation in support of Naisbitt's claims. Instead, one finds a breathlessly assembled jumble of one- 
liners ("Japan was the star performer of the industrial world, but it is now the sick economy of Asia"), anecdotal material ("Of the world's top ten tallest buildings scheduled to be completed in the 1990s, nine are in Asia") and mini-homilies ("The West now needs the East a lot more than the East needs the West") without so much as an attempt to connect these various bits and pieces by anything more substantial than interviews and newspaper articles. The book has all the sophistication and subtlety of a cartoon strip.

Naisbitt calls himself "the world's leading trend forecaster", but rather than being a forecaster, he is in reality a resister who repackages today's news and then sells it in glitzy packages. Caveat emptor.

We should like to draw our readers' attention to the following important reference work that has just been published.

\author{
Alan J.K. Sanders. Historical \\ Dictionary of Mongolia \\ Lanham, MD: Scarecrow Press, 1996. \\ 240 p. ISBN 0-8108-3077-9. US\$47.50. \\ (Asian Historical Dictionaries; no. 19)
}

